\title{
Some Physicochemical Parameters of Keana Salt Lake and Domestic Water Sources in the Salt Lake Community, Nasarawa State, Nigeria
}

\author{
Sule Philip Ivoms Ogah \\ Department of Chemistry, Faculty of Science, Federal University of Lafia, Lafia, Nasarawa, Nigeria
}

Email address:

suleimanogah@gmail.com

\section{To cite this article:}

Sule Philip Ivoms Ogah. Some Physicochemical Parameters of Keana Salt Lake and Domestic Water Sources in the Salt Lake Community, Nasarawa State, Nigeria. Science Journal of Analytical Chemistry. Vol. 8, No. 3, 2020, pp. 111-116. doi: 10.11648/j.sjac.20200803.14

Received: May 19, 2020; Accepted: July 13, 2020; Published: August 5, 2020

\begin{abstract}
Concerns have been raised on levels of some physicochemical parameters in Salt Lake water systems all over the world. In a developing country like Nigeria, Salt Lakes are pertinent domestic water sources in communities where they are found. This study examined the levels of selected physicochemical parameters (Chlorine, $\mathrm{pH}$, Temperature, Total dissolved solids, Electrical conductivity, Total alkalinity, Total hardness, Nitrate, Sulphate and Phosphate) in water samples collected from Keana Salt Lake Nasarawa State, Nigeria and drinking water sources around the Salt Lake, in order to compare them with permissible limits. Water samples were collected in triplicates from five locations (two surface and three underground water sources) and analyzed using standard methods. Analysis of variance (ANOVA) was applied to determine significant differences in concentration ( $p \leq 0.05$ ) based on sample location. The results are presented as Mean \pm standard error values. Results show that Mean concentration levels of TDS and electrical conductivity were above WHO limits in the surface water samples. Chlorine, temperature, alkalinity, total hardness, Nitrate, Sulphate and Phosphate were all within their respective WHO permissible limits. Correlation analyses show that electrical conductivity, Nitrate and TDS were the variable significantly positively correlated among the physicochemical parameters examined in the study. On that note, the study recommends carrying out further research on heavy metals and microbial concentrations of water sources around Keana Salt Lake.
\end{abstract}

Keywords: Physicochemical Parameters, Salt Lake, Nitrate, TDS, Electrical Conductivity

\section{Introduction}

Water is essential for sustaining life because, all living organisms require water to maintain good health and vigor. Water acts as a medium for both chemical and biochemical reactions that continually take place in any environmental space [1]. The main sources of fresh water are ground and surface water which can be affected by the presence of pollutants and poor management [2]. The physicochemical parameters of water bodies are either due to natural processes or as a result of anthropogenic activities [3] which may have geospatial implications in terms of how these parameters are distributed in a given area [4]. Salt lakes are usually a land locked body of water which has high salinity and other minerals significantly higher than other similar fresh water sources [5].

Though salt lakes may be socio-economically important, they are capable of causing problems for human health and negatively affect agricultural activities in any community where they are found $[6,7]$. Pre-eclampsia and gestational hypertension in pregnant women living in the southwestern coast of Bangladesh, have been linked to saline contamination of drinking water sources [8]. Similarly, studies undertaken on Okposi and Uburu salt lakes in Ebonyi State, Nigeria by administering samples of these lake waters to animals reported cardiovascular toxicity in albino rats [9], while sperm quantity in the caudal epididymis of Sprague-Dawley rats significantly decreased especially when the dose and period of exposure were increased [10].

In a study investigating variability of bromine and chlorine isotopes in saline lake systems by analyzing evaporation, shoreline gases and brines, showed that chlorine and its 
isotope are more active in the brine than in saline state in the lake systems studied [11]. However, a study of several saline lakes in the Ishim steppe region of northern Kazakhstan show that most of the lakes have high chloride-ion concentrations of up to $16 \mathrm{~g} / \mathrm{L}$ with ratio of more than 10 for $\mathrm{Cl} / \mathrm{SO}_{4}$ in most of the lakes studied [12]. Similarly, chlorine ion concentration in Nandoni brackish dam in Limpopo province, South Africa ranged between $25.5 \mathrm{mg} / \mathrm{L}$ and $64.6 \mathrm{mg} / \mathrm{L}$ in autumn and summer respectively [13]. Geochemical analyses of the Sutton salt lake, New Zealand showed high levels of phyllosilicates (including chlorite) with average $\mathrm{pH}$ level of about 9 within the lake [14]. Therefore, it is not surprising that examination of water samples collected from saline ponds within Awe and Keana Local Government Areas in Nasarawa State, Nigeria for several physicochemical parameters showed that many parameters like chlorine, calcium carbonate, total dissolved solids (TDS) and electrical conductivity were well above WHO standard for each of these parameters [15]. Similarly, a study carried out on Lake Katwe, a salt lake in Uganda showed that a very high value of $27,550 \mathrm{mg} / \mathrm{L}$ was obtained for TDS with percentage-by-weight for sodium chloride, carbonates and Sulphates having calculated values of $13.7 \%, 16.9 \%$ and $17.2 \%$ respectively among others [16]. Also, physicochemical assessment of groundwater samples collected from Salt Lake City, West Bengal, India, showed that Total dissolved solids was $746 \mathrm{mg} / \mathrm{L}$ which exceeded permissible limits by over $200 \mathrm{mg} / \mathrm{L}$ [17]. Analysis of electrical conductivity and TDS of water samples from Rudrasagar Lake, India, indicated electrical conductivity of $53.76 \mu \mathrm{s} / \mathrm{cm}$ and $104.35 \mu \mathrm{s} / \mathrm{cm}$ in the winter and summer seasons respectively, while TDS were $35.23 \mathrm{mg} / \mathrm{L}$ and 68.75 $\mathrm{mg} / \mathrm{L}$ with minimum and maximum values in the winter and monsoon seasons respectively [18]. Physicochemical examination of groundwater samples collected from a number of wells in the southern Salt lake region, USA indicated that dissolved Sulphate concentrations had a median value of $136 \mathrm{mg} / \mathrm{L}$ while alkalinity (as $\mathrm{CaCO}_{3}$ ) ranged from $68 \mathrm{mg} / \mathrm{L}$ to $659 \mathrm{mg} / \mathrm{L}$ with a median concentration value of $308 \mathrm{mg} / \mathrm{L}$ [19]. In the same vein, evaluation of water samples collected from salt ponds around Bhavnagar coast, India for various physicochemical parameters indicate a range of between $40 \mathrm{~g} / \mathrm{L}$ to $132 \mathrm{~g} / \mathrm{L}$ for total hardness while phosphate levels ranged from $3 \mu \mathrm{g} / \mathrm{L}$ to $32 \mu \mathrm{g} / \mathrm{L}$ [20]. Seasonal assessment of brackish water samples from the inlet of the Nandoni dam in Limpopo province, South Africa had nitrate concentrations ranging from 5.98 $\mathrm{mg} / \mathrm{L}$ to about $16 \mathrm{mg} / \mathrm{L}$ while Sulphate concentrations were between $0.3 \mathrm{mg} / \mathrm{L}$ and $0.9 \mathrm{mg} / \mathrm{L}$, within the same timeframe [13]. Chemical evaluation of groundwater samples collected from three salt lakes in East Transbaikalia, Russia indicated that electrical conductivity values ranged from -423 to $281 \mathrm{mV}$ while Sulphate mean concentrations ranged from $30.4 \mathrm{mg} / \mathrm{L}$ to $88.5 \mathrm{mg} / \mathrm{L}$ for the samples examined [21]. Analyses of saline soil samples from different parts of Kenya for physicochemical variables indicated moderate to high concentrations of sodium chlorides, sulfates and bicarbonates in southern and coastal areas of the African country [22]. Even though analysis of heavy metal ions in water sources around Keana salt lake have been recently reported [23], there is a need to investigate physicochemical dimensions of drinking water sources around the lake. The presence of Salt Lake in Keana is a sight of attraction and tourism especially in the local craft of salt processing by the aged women. The salt obtained after heating is not subjected to any laboratory analysis, but are being consumed directly by the locals. The settlers depend on the lake for domestic use in both dry and rainy seasons. There is no quality control in the local salt processing from Keana Salt Lake by the locals, and no scientific procedure followed. On that note, the study aimed at ascertaining the physicochemical parameters of Keana Salt Lake and other water sources within the community, by determining the levels of some physicochemical parameters such as chlorine, $\mathrm{pH}$, temperature, total dissolved solids, electrical conductivity, total alkalinity, total hardness, nitrate, sulfate and phosphate of the surface and groundwater samples collected from the study area in comparison with World Health Organization (WHO) standards [24-26].

\section{Materials and Methods}

\subsection{Study Area}

This study was carried out on Keana Salt Lake and other sources of water for domestic consumptions in the community located in Keana Local Government Area of Nasarawa State Nigeria. It lies within latitude $8^{0} 09^{\prime} 33.0^{\prime \prime} \mathrm{N}$ and longitude $8^{0} 47^{\prime} 51.1^{\prime E}$. The Salt Lake is locally known as "Akyana Gbogbo" by the inhabitants, and the Keana town was believed to derive its name from the lake. Keana is one of the thirteen Local Government Areas of Nasarawa State, Nigeria. It has an area of $1,048.1 \mathrm{~km}^{2}$ and a population of about 80,000 according to the Nigerian 2006 census.

\section{2. Sample Collection}

Five areas SG1, SG2, SG3 for the groundwater, and SW1 and SW2 for surface salt water, were selected for sampling. The samplings were carried out in rainy season in the month of June. Five plastic containers of a liter capacity each were used in collecting the samples. Each container was washed with detergent, rinsed properly with distilled water and sun dried. The container was rinsed again with the sample water at the point of sample collection and the rinsed water thrown out of the sampling area. Each sample was immediately covered and labeled before preserving them at low temperature of $4^{\circ} \mathrm{C}$ using ice chest. All the samples were prepared according to standard methods [27].

Table 1. Sample Identification.

\begin{tabular}{llll}
\hline S/N & Sample code & Sample location & Water source \\
\hline 1. & SG1 & General hospital & Motorized borehole \\
2. & SG2 & Town center & Manual pump borehole \\
3. & SG3 & Town center & Well water \\
4. & SW1 & Keana salt lake & Salt lake water \\
5. & SW2 & Keana salt lake & Filtrate from salt water \\
\hline
\end{tabular}




\subsection{Analytical}

\subsubsection{Determination of Temperature}

The temperature was measured in the field using mercury filled Celsius thermometer. The thermometer was immersed in the sample long enough to allow accurate and stable reading and the result was recorded immediately.

\subsubsection{Determination of $\mathrm{pH}$}

The $\mathrm{pH}$ was measured using a $\mathrm{pH}$ meter. The electrode was thoroughly washed with distilled water and also re-washed with a portion of the sample before use. The $\mathrm{pH}$ meter was standardized using buffer solutions of 4.0, 7.0 and 10.0. The $\mathrm{pH}$ levels of the samples were measured and recorded.

\subsubsection{Determination of Conductivity}

The conductivity of the salt water and the ground water samples were determined in the field using conductivity meter. The power key and conductivity key were switched on. The probe was dipped below the surface of each sample and time was allowed for the reading to stabilize. The reading was recorded. The electrode was rinsed clean with distilled water between each sample determination and further rinsed with a portion of the sample to be determined.

\subsubsection{Determination of Total Hardness}

Total hardness was determined using titration method.

Testing of water samples

Twenty (20) $\mathrm{mL}$ of each water sample was pipetted and transferred to a clean $250 \mathrm{~mL}$ conical flask. Two (2) $\mathrm{mL}$ of Ammonia buffer solution was added to the water samples to maintain the $\mathrm{pH}$ between 9 and 10. Two drops of EBT indicator were added to each of the solution in the conical flask and the samples turned wine red in colour. Each solution was titrated against $0.02 \mathrm{M}$ EDTA solution. The appearance of blue colour indicated the end point of the titration. The titration was repeated three times and the values recorded.

$$
\begin{gathered}
\mathrm{CaCO}_{3}+\mathrm{EDTA}^{4-}{ }_{(\mathrm{aq})} \rightarrow \mathrm{Ca}\left(\mathrm{EDTA}^{2-}{ }_{(\mathrm{aq})}+\mathrm{CO}_{3}{ }^{2-}{ }_{(\mathrm{aq})}\right. \\
\mathrm{MgCO}_{3}+\mathrm{EDTA}^{4-}{ }_{(\mathrm{aq})} \rightarrow \mathrm{Mg}\left(\mathrm{EDTA}^{2-}{ }_{(\mathrm{aq})}+\mathrm{CO}_{3}{ }^{2-}{ }_{(\mathrm{aq})}\right.
\end{gathered}
$$

Calculation of total hardness

$$
\text { Total hardness }=\frac{(\text { Volume of EDTA }) \times \mathrm{N} \times 50 \times 1000}{\text { Volume of sample used }}
$$

$\mathrm{N}=$ Normality of EDTA $=(0.02 \mathrm{~N})$

Equivalent weight of $\mathrm{CaCO}_{3}=50$

1000 is used for the conversion of the sample size from $\mathrm{ml}$ to $\mathrm{L}$

\subsubsection{Total Alkalinity}

Total alkalinity was determined using titration method.

Testing of water sample

For each sample, the burette was rinsed with the $0.02 \mathrm{~N}$ $\mathrm{H}_{2} \mathrm{SO}_{4}$ before use. The burette was then filled with $0.02 \mathrm{~N}$ $\mathrm{H}_{2} \mathrm{SO}_{4}$ and adjusted to zero. One hundred (100) $\mathrm{mL}$ of water sample was measured into a $250 \mathrm{~mL}$ conical flask. Three drops of methyl orange indicator were added. The solution was titrated against $0.02 \mathrm{~N} \mathrm{H}_{2} \mathrm{SO}_{4}$ until colour changed from yellow to red which marked the end point. The titration was repeated three times and the values recorded.

Calculation of Total Alkalinity

$$
\text { Total alkalinty }=\frac{\left.\left(\text { Volume of } \mathrm{H}_{2} \mathrm{SO}_{4}\right) \times \mathrm{N} \times 50 \times 1000\right)}{\text { Volume of sample used }}
$$

$\mathrm{N}=$ Normality of $\mathrm{H}_{2} \mathrm{SO}_{4}=(0.02 \mathrm{~N})$

Equivalent weight of $\mathrm{CaCO}_{3}=50$

1000 was used for the conversion of the sample size from $\mathrm{ml}$ to $\mathrm{L}$.

\section{Results and Discussion}

The results obtained were subjected to statistical analysis using one-way analysis of variance (ANOVA), on SPSS version 21. Difference was considered significant at $\mathrm{P} \leqslant 0.05$. Physicochemical parameters analyzed are presented in Table 2. The findings show that all the parameters analyzed were significant in terms of sample location (ANOVA $\mathrm{p}$-value $<0.001)$. Mean values for chlorine ranged from $0.025 \pm 0.002 \mathrm{mg} / \mathrm{L}$ in $\mathrm{SG} 1$, to $0.829 \pm 0.001 \mathrm{mg} / \mathrm{L}$ in $\mathrm{SW} 2$. Chlorine concentrations are quite low in the water samples studied, unlike in South Africa where mean concentration

\begin{tabular}{|c|c|c|c|c|c|c|c|}
\hline Parameter & WHO limits & SW1 & SW2 & SG1 & SG2 & SG3 & $P$ value \\
\hline Chlorine (mg/L) & 250 & $0.106 \pm 0.001$ & $0.829 \pm 0.001$ & $0.025 \pm 0.002$ & $.036 \pm 0.001$ & $0.119 \pm 0.001$ & 0.000 \\
\hline $\mathrm{pH}$ & $6.5-8.5$ & $7.563 \pm 0.009$ & $7.857 \pm 0.015$ & $6.343 \pm 0.009$ & $7.070 \pm 0.012$ & $6.953 \pm 0.009$ & 0.000 \\
\hline Temperature $\left({ }^{\circ} \mathrm{C}\right)$ & 32.0 & $25.167 \pm 0.08$ & $26.767 \pm 0.088$ & $25.267 \pm 0.03$ & $24.967 \pm 0.12$ & $26.133 \pm 0.03$ & 0.000 \\
\hline TDS (mg/L) & 500.00 & $233.333 \pm 3.333$ & $8273.333 \pm 3.333$ & $306.667 \pm 3.333$ & $206.667 \pm 6.667$ & $103.333 \pm 3.333$ & 0.000 \\
\hline $\mathrm{EC}(\mu \mathrm{s} / \mathrm{cm})$ & 500.00 & $353.333 \pm 3.333$ & $12373.333 \pm 3.333$ & $453.333 \pm 3.333$ & $313.333 \pm 3.333$ & $166.667 \pm 3.333$ & 0.000 \\
\hline Alkalinity (mg/L) & 120.0 & $30.227 \pm 0.015$ & $15.460 \pm 0.020$ & $20.207 \pm 0.007$ & $43.607 \pm 0.007$ & $38.010 \pm 0.006$ & 0.000 \\
\hline Hardness $(\mathrm{mg} / \mathrm{L})$ & 200.0 & $20.063 \pm 0.019$ & $9.627 \pm 0.007$ & $2.413 \pm 0.009$ & $1.603 \pm 0.003$ & $7.213 \pm 0.003$ & 0.000 \\
\hline Sulphate $(\mathrm{mg} / \mathrm{L})$ & 400.0 & $13.670 \pm 0.012$ & $10.433 \pm 0.068$ & $18.387 \pm 0.013$ & $9.750 \pm 0.006$ & $11.077 \pm 0.012$ & 0.000 \\
\hline Phosphate (mg/L) & NS & $0.460 \pm 0.006$ & $0.947 \pm 0.009$ & $0.333 \pm 0.009$ & $0.663 \pm 0.007$ & $0.023 \pm 0.007$ & 0.000 \\
\hline
\end{tabular}
levels of over $40 \mathrm{mg} / \mathrm{L}$ were identified in Nandoni brackish dam, South Africa [13].

Table 2. Mean \pm standard error values of physicochemical parameters in water samples from Keana Lake Community Nasarawa State Nigeria.

TDS $=$ Total dissolved solids; EC = Electrical conductivity

In terms of $\mathrm{pH}$ level in the water samples, mean values varied from a low of 6.343 in SG1 to a high of 7.857 in SW2, indicating that only the sample SG1 was below WHO limit for $\mathrm{pH}$ in the analyzed water samples. The levels of $\mathrm{pH}$ identified in the study are a bit lower than those reported by Craw and Beckett [14] in analyzing several water samples 
from Sutton Salt Lake, New Zealand, where mean level for $\mathrm{pH}$ was 9 . Temperature of the water samples ranged from $24.967 \pm 0.12^{\circ} \mathrm{C}$ in $\mathrm{SG} 2$ to $26.767 \pm 0.088^{\circ} \mathrm{C}$ in $\mathrm{SW} 2$. Temperature ranges in all the water samples were at least $5^{\circ} \mathrm{C}$ lower than WHO limit, indicating that temperature was stable in the water samples studied. With respect to TDS in the water samples, range varied from a low of $103.333 \pm 3.333$ $\mathrm{mg} / \mathrm{L}$ in SG3, to a high of $8273.333 \pm 3.333 \mathrm{mg} / \mathrm{L}$ in SW2.

TDS mean concentration levels were all below WHO limit for underground water systems sampled in the study. However, TDS concentration level of about $746 \mathrm{mg} / \mathrm{L}$ which is above WHO limit, have been determined from analyzing underground water samples in Salt Lake City, India [17]. Furthermore, higher concentrations of TDS have also been reported in Uganda, where levels of up to $27,000 \mathrm{mg} / \mathrm{L}$ were determined from analysis of Lake Katwe water samples [16].

Mean concentration levels of electrical conductivity in the water samples studied ranged from a low of $166.667 \pm 3.333$ $\mu \mathrm{s} / \mathrm{cm}$ in SG3, to a high of $12373.333 \pm 3.333 \mu \mathrm{s} / \mathrm{cm}$ in SW2. However, all the groundwater samples had electrical conductivity concentration values that were below WHO limit; a mean value of $453.333 \pm 3.333 \mu \mathrm{s} / \mathrm{cm}$ was recorded for SG1 which is the highest for the three groundwater samples in the study. However, Pal et al. [18] reported electrical conductivity values ranging from, $53.76 \mu \mathrm{s} / \mathrm{cm}$ to $104.35 \mu \mathrm{s} / \mathrm{cm}$, from analyses of water samples from Rudrasagar Lake, India.

Alkalinity levels in the water samples studied ranged from $15.460 \pm 0.020 \mathrm{mg} / \mathrm{L}$ in SW2, to $43.607 \pm 0.007 \mathrm{mg} / \mathrm{L}$ in $\mathrm{SG} 2$, indicating that none of them exceeded the WHO limit. Higher levels of alkalinity were identified in southern Salt Lake region, United States with concentrations as high as 659 $\mathrm{mg} / \mathrm{L}$ in some of the water samples examined [19].

In terms of total hardness levels in the water samples, mean concentration levels ranged from a low of $1.603 \pm 0.003$ $\mathrm{mg} / \mathrm{L}$ in SG2 to a high of $20.063 \pm 0.019 \mathrm{mg} / \mathrm{L}$ in SW1. In addition, hardness in groundwater samples was lower than those from surface water; groundwater samples had a maximum mean value of $7.213 \pm 0.003 \mathrm{mg} / \mathrm{L}$ calculated from the water sample in SG3. Study result on hardness is different from concentration levels of hardness in water samples collected from Bhavnagar salt ponds, which ranged between $40000 \mathrm{mg} / \mathrm{L}$ and $132000 \mathrm{mg} / \mathrm{L}$. Significantly higher hardness in water samples from Bhavnagar salt pond may be attributed to being close to the gulf of Khambath, in the Arabian sea, unlike Keana Salt Lake that is far from any ocean or sea.

Mean concentration levels for Nitrate in the water samples studied ranged from $12.880 \pm 0.012 \mathrm{mg} / \mathrm{L}$ in $\mathrm{SG} 2$ to $37.653 \pm 0.009 \mathrm{mg} / \mathrm{L}$ in SW2, indicating that groundwater samples had less concentrations than surface water. All samples studied had nitrate levels below WHO limit. Similar concentration levels $(5.88 \mathrm{mg} / \mathrm{L}$ and $16 \mathrm{mg} / \mathrm{L})$ were also identified in analyzed water samples from Nandoni brackish dam, South Africa [13].

Study findings show that mean concentration values of Sulphate in the water samples studied, ranged from $9.750 \pm 0.006 \mathrm{mg} / \mathrm{L}$ in $\mathrm{SG} 2$, to $18.387 \pm 0.013 \mathrm{mg} / \mathrm{L}$ in $\mathrm{SG} 1$. Though all the nitrate concentrations were below WHO limits, the nitrate concentrations of underground water samples were higher than surface water samples. However, Borzenko and Shvartsev [21] reported higher concentrations of between $30.4 \mathrm{mg} / \mathrm{L}$ and $88.5 \mathrm{mg} / \mathrm{L}$ for Nitrate in analyzed water samples from three salt lakes in Russia. In addition, Sulphate levels of up to $136 \mathrm{mg} / \mathrm{L}$ have been determined from analyses of water samples from southern Salt Lake region, United States [19].

Mean concentration levels of phosphate in the water samples studied ranged from $0.023 \pm 0.007 \mathrm{mg} / \mathrm{L}$ in $\mathrm{SG} 3$ to $0.947 \pm 0.009 \mathrm{mg} / \mathrm{L}$ in SW2. However, concentrations as low as $32 \mu \mathrm{g} / \mathrm{L}$ for phosphate from analyses of Bhavnagar salt ponds' water samples, have also been reported [20]. Table 2 shows Pearson's product-moment correlation of the physicochemical parameters analyzed in the study.

The correlation results show that Electrical conductivity was positively correlated with TDS $(r=.992, p<0.01)$, while Chlorine was also positively correlated with both TDS ( $\mathrm{r}$ $=.991, \mathrm{p}<0.01)$ and electrical conductivity $(\mathrm{r}=.991, \mathrm{p}<0.01)$. Nitrate concentration levels were also positively correlated with total hardness $(.917, \mathrm{p}<0.05)$. Levels of $\mathrm{pH}$, temperature, total alkalinity, Sulphate and Phosphate were not significantly correlated with any of the parameters examined in the study. Furthermore, all the insignificantly correlated variables were those below WHO permissible limits, indicating that their correlation coefficients may be related to their mean concentration levels.

Table 3. Correlation coefficients of physicochemical parameters in water samples from Keana Salt Lake

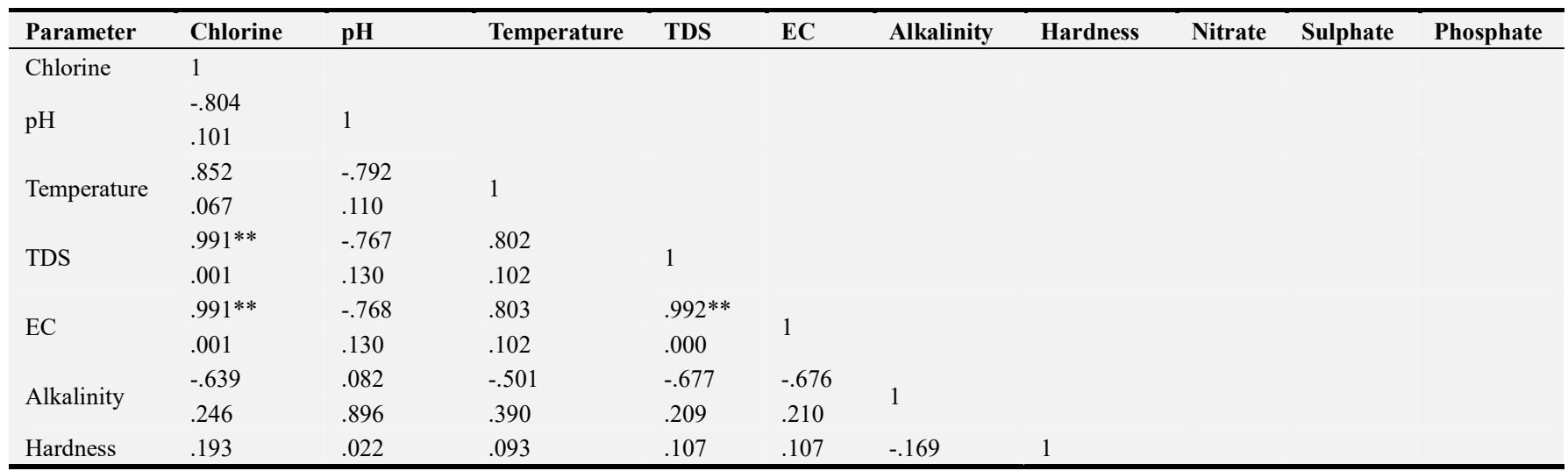




\begin{tabular}{|c|c|c|c|c|c|c|c|c|c|c|}
\hline Parameter & Chlorine & pH & Temperature & TDS & EC & Alkalinity & Hardness & Nitrate & Sulphate & Phosphate \\
\hline \multirow{3}{*}{ Nitrate } & .756 & .972 & .882 & .864 & .863 & .786 & & \multirow{3}{*}{1} & \multirow{5}{*}{1} & \multirow{7}{*}{1} \\
\hline & .389 & .002 & .134 & .347 & .347 & -.469 & $.917 *$ & & & \\
\hline & .517 & .998 & .830 & .567 & .567 & .425 & .028 & & & \\
\hline \multirow{2}{*}{ Sulphate } & -.393 & .826 & -.367 & -.339 & -.340 & -.456 & -.034 & .091 & & \\
\hline & .513 & .085 & .544 & .577 & .576 & .441 & .957 & .885 & & \\
\hline \multirow{2}{*}{ Phosphate } & .691 & -.510 & .228 & .750 & .750 & -.398 & .051 & .355 & -.349 & \\
\hline & .196 & .380 & .712 & .144 & .144 & .507 & .935 & .558 & .564 & \\
\hline
\end{tabular}

$\mathrm{TDS}=$ Total dissolved solids; $\mathrm{EC}=$ Electrical conductivity. $* *=$ Correlation significant at the 0.01 level; $*=$ Correlation is significant at the 0.05 level.

\section{Conclusion}

The study findings have demonstrated the physicochemical characteristics of water samples around Keana Salt Lake and the Salt Lake itself. Mean concentration levels for TDS and electrical conductivity were the only physicochemical parameters that exceeded their respective WHO limits. The remaining parameters examined in the study (chlorine, $\mathrm{pH}$, temperature, alkalinity, hardness, Nitrate, Sulphate and Phosphate) were all within WHO limits, with respect to their respective mean concentration levels. In terms of correlation with other physicochemical parameters, study findings have shown that mean concentrations of TDS, electrical conductivity and Nitrate were the only variables strongly correlated with each other. Consequently, the study findings indicate that water sources within and around Keana Salt Lake have higher levels of dissolved solids and electrical charges, which could be attributed to the salt prevalence in the study area However, water quality may depend on many other factors beyond the scope of this study. A study on microbial constituents of water sources around Keana Salt Lake and the Salt Lake itself may be of interest so as to understand possible environmental health consequences. It is worthy to note that this study was carried out during the rainy season. It will be of interest to carry out a similar study during the dry season and compare the result obtained with the result of this study so as to have comprehensive data on the trend of the physicochemical parameters across the two major seasons of the study area.

\section{Acknowledgements}

The indispensable contribution of my M. Sc. Student Onwukwe Friday is hereby adequately acknowledged.

\section{References}

[1] Rajankar, P. N., Gulhane, S. R., Tambekar, D. H., Ramteke, D. S., and Wate, S. R. (2009). Water quality assessment of groundwater resources in Nagpur region (India) based on WQI. $\begin{array}{llll}\text { E-Journal of Chemistry, } 6 & \text { (3): 905-908. }\end{array}$ https://doi.org/10.1155/2009/971242

[2] Ameloko, A. A., and Ayolabi, E. A. (2018). Geophysical assessment for vertical leachate migration profile and physicochemical study of groundwater around the Olusosun dumpsite Lagos, south-west Nigeria. Applied Water Science, 8 (5). https://doi.org/10.1007/s13201-018-0775-x
[3] Ibekwe, A. M., Murinda, S. E., and Graves, A. K. (2011). Genetic diversity and antimicrobial resistance of Escherichia coli from human and animal sources uncovers multiple resistances from human sources. PLoS One, 6 (6).

[4] Balakrishnan, P., Saleem, A., and Mallikarjun, N. D. (2011). Groundwater quality mapping using geographic information system (GIS): A case study of Gulbarga City, Karnataka, India. African Journal of Environmental Science and Technology, 5 (12): 1069-1084.

[5] Deocampo, D. M. and Jones, B. F. "Geochemistry of Saline Lakes,” Treatise Geochemistry Second Ed., vol. 7, pp. 437-469, 2013, doi: 10.1016/B978-0-08-095975-7.00515-5.

[6] Warrence, N. J., Bauder, J. W., and Pearson, K. E. (2002). Basics of salinity and sodicity effects on soil physical properties. Departement of Land Resources and Environmental Sciences, Montana State University-Bozeman, MT, 129.

[7] Chaparzadeh, N., Aftabi, Y., Dolati, M., Mehrnejad, F., and Pessarakli, M. (2014). Salinity tolerance ranking of various wheat landraces from the west of the Urmia saline lake in Iran by using physiological parameters. Journal of Plant Nutrition, 37 (7), 1025-1039.

[8] Khan, A., Mojumder, S. K., Kovats, S., and Vineis, P. (2008). Saline contamination of drinking water in Bangladesh. The $\begin{array}{llll}\text { Lancet, } & 371 & \text { (9610): } & 385 .\end{array}$ https://doi.org/10.1016/S0140-6736(08)60197-X

[9] Agbafor, K. N., Ajah, P. M., Offor, C. E., Igwenyi, I. O., and Ibiam, U. A. (2011). Examination of cardiovascular toxicity and trace elements status in albino rats Treated with Okposi and Uburu salt lakes (Nigeria). Research Journal of Environmental Toxicology, $\quad 5 \quad$ (3): $229-234$. https://doi.org/10.3923/rjet.2011.229.234

[10] Ogbanshi, M. E., Akubugwo, E. I., Onwuchekwa, O., Ali, F. U., Ebenyi, L. N., Offor, C. E., and Orinya, O. F. (2015). Administration of water and salt samples from Okposi and Uburu Nigerian Salt Lakes induce Oxidative stress in the reproductive parameters of adult male Sprague-Dawley rats. Global Journal of Pharmacology, 9 (4): 345-351. https://doi.org/10.5829/idosi.gjp.2015.9.4.10152

[11] Hanlon, C., Stotler, R., Frape, S., and Gwynne, R. (2017). Comparison of $\delta 81 \mathrm{Br}$ and $\delta 37 \mathrm{Cl}$ composition of volatiles, salt precipitates, and associated water in terrestrial evaporative saline lake systems. Isotopes in Environmental and Health Studies, $\quad 53 \quad$ (5): $446-465$ https://doi.org/10.1080/10256016.2017.1324856.

[12] Kolpakova, M. N., Gaskova, O. L., Naymushina, O. S., Karpov, A. V., Vladimirov, A. G., and Krivonogov, S. K. (2019). Saline lakes of Northern Kazakhstan: Geochemical correlations of elements and controls on their accumulation in water and bottom sediments. Applied Geochemistry, 107: 8-18. https://doi.org/10.1016/j.apgeochem.2019.05.013. 
[13] Nthunya, L. N., Maifadi, S., Mamba, B. B., Verliefde, A. R., and Mhlanga, S. D. (2018). Spectroscopic determination of water salinity in brackish surface water in Nandoni Dam, at Vhembe District, Limpopo Province, South Africa. Water (Switzerland), 10 (8). https://doi.org/10.3390/w10080990.

[14] Craw, D., and Beckett, S. (2004). Water and sediment chemistry of Sutton Salt Lake, east Otago, New Zealand. New Zealand Journal of Marine and Freshwater Research, 38 (2): 315-328. https://doi.org/10.1080/00288330.2004.9517240.

[15] Abiola, K., Funmilola, A., Medugu, N. I., and Ayuba, H. K. (2014). Variability of Brine Water Quality in Keana and Awe, Nasarawa State, Nigeria. Unique Journal of Engineering and Advanced Sciences (UJEAS), 2 (4): 36-45.

[16] Kirabira, J. B., Kasedde, H., and Ssemukuuttu, D. (2013). Towards the improvement of salt extraction at Lake Katwe, Uganda. International Journal of Scientific and Technology Research, 2 (1): 76-81.

[17] Banerji, S., and Mitra, D. (2017). Evaluation of water resource management in Salt Lake City, West Bengal, India. Hydrological Sciences Journal, 62 (12): 1980-1994. https://doi.org/10.1080/02626667.2017.1351028.

[18] Pal, M., Samal, N. R., Roy, P. K., and Roy, M. B. (2015). Electrical Conductivity of Lake Water as Environmental Monitoring-A Case Study of Rudrasagar Lake. IOSR Journal of Environmental Science, Toxicology and Food Technology, 9, $66-71$.

[19] Thiros, S. A. (2003). Quality and sources of shallow ground water in areas of recent residential development in Salt Lake Valley, Salt Lake County, Utah. http://pubs.water.usgs.gov/wri034028.
[20] Patadia, A. R. (2015). Analysis of Physico-chemical parameters of salt pans at Newport and Nari situated around Bhavnagar Coast. Journal of Ecobiotechnology, 7. https://doi.org/10.19071/jebt.2015.v7.200.

[21] Borzenko, S. V., and Shvartsev, S. L. (2019). Chemical composition of salt lakes in East Transbaikalia (Russia). Applied Geochemistry, 103: 72-84. https://doi.org/10.1016/j.apgeochem.2019.02.014

[22] Mugai, E. N. (2004). Salinity characterization of the Kenyan saline soils. Soil Science and Plant Nutrition, 50 (2): 181-188. https://doi.org/10.1080/00380768.2004.10408467.

[23] Ogah, S. P. I. (2020). Heavy metals in Keanasalt lake and some sources of drinking water within the Keanasalt lake community, Nasarawa State, Nigeria. Science Journal of Analytical Chemistry, 8 (2): 56-59. doi: 10.11648/j.sjac.20200802.13

[24] W.H.O., "Sulfate in drinking-water," Backgr. Doc. Dev. WHO Guidel. Drink. Qual., pp. 1-8, 2004.

[25] W.H.O., "Guidelines for drinking-water quality [electronic resource]: incorporating first addendum. Vol. 1, Recommendations," 2006.

[26] W.H.O., "nitrite in drinking-water background document for development of WHO guidelines for drinking-water quality," Geneva World Heal. Organ., 2011.

[27] Okeke, P., and Adinna, E. (2013). Water Quality Study of Ontamiri River in Owerri, Nigeria. Universal Journal of Environmental Research \& Technology, 3 (6). 